\title{
ERCP among Cirrhotics: What are the differences?
}

Mohamed H. Emara ${ }^{1}$, Hassan E. Elbatee ${ }^{1}$, Mohamed I. Radwan ${ }^{2}$, Ibrahim F Amer ${ }^{1}$, Mariam S. Zaghloul ${ }^{1}$, Mohamed H. Ahmed ${ }^{1}$, Aya M. Mahrous $^{1}$, Soha A. Elhawari ${ }^{2}$, Eslam M. Elshenawy ${ }^{1}$

${ }^{1}$ Department of Hepatology, Gastroenterology and Infectious Diseases, Faculty of Medicine, Kafrelsheikh University, Kafrelsheikh, Egypt.

${ }^{2}$ Department of Tropical Medicine, Faculty of Medicine, Zagazig University, Zagazig, Egypt.

Corresponding Author Mohamed H Emara, $M D$

\section{Mobile:}

$+201002724482$

\section{E mail:} emara_20007@yahoo. com,

Key words: ERCP; Cirrhosis; Bleeding
The endoscopic retrograde cholangiopancreatography (ERCP) is considered a main therapeutic intervention in the management of biliary and pancreatic disorders. In the average risk populations it is associated with adverse events. The most common adverse event is postERCP pancreatitis. Patients with liver cirrhosis are increasingly seen in ERCP theaters with different indications for the ERCP. Because cirrhotic patients are prone to complications it is expected that they develop more adverse events when operated with ERCP. Bleeding diathesis is the most serious because of the underlying coagulopathy and thrombocytopenia that are commonly encountered among them in particular with advanced Child class. In this mini review we discussed how different is the ERCP among cirrhotics regarding the expected benefits and the reported risks and we showed our experience in dealing with this subgroup of patients. The art of managing cirrhotic patients with ERCP is a team work and not a one man show.

\section{INTRODUCTION}

The development of endoscopic retrograde cholangiopancreatography (ERCP) in late sixties and early seventies of the last century was a major breakthrough in the management of biliary and pancreatic disorders. Since its development major improvements, developed over decades, in the endoscopic management had been evolved including invasive interventions and these were seen as improvements in the outcomes of the procedure [1].

The idea in ERCP was to cannulate the duodenal papilla using a side viewing endoscope and then inject a contrast in the biliary (most of the time) and pancreatic ductal system to delineate it, identify the pathology there and then plan the treatment. Nowadays ERCP is no more performed for diagnostic purposes except in very limited situations due to the parallel major improvements in noninvasive modalities particularly
MRI including MRCP. MRCP replaced the diagnostic role of ERCP at both low cost and low risk. This means that ERCP is mainly a therapeutic maneuver and is classified as an advanced endoscopic procedure that requires special orientation and training. Different endoscopic societies e.g. ASGE, ESGE had a specific training curriculum and competency checklists for an endoscopist to be privileged for practicing ERCP and that is why not all endoscopic theaters are armed with ERCP facilities. In fact different societies for practicing GIT endoscopy requires a minimum number of cases to be performed before an endoscopist is authorized to practice ERCP independently [1]. Moreover, these societies recommended also a minimum number of cases to be operated yearly for an endoscopist to maintain his quality of performing ERCP because low volume of practice is inversely correlated with the rate of adverse 
events, the low volume is the higher the adverse events rate are $[\mathbf{2 , 3}]$.

Different treatment options are offered with ERCP for both biliary and pancreatic systems. These include, but not limited to, sphincterotomy (cutting the duodenal papilla and sphincter of Oddi), removal of stones (either directly or after its fragmentation by many tools), dilatation of strictures, drainage of pus, insertion of stents among others. To perform all these interventions different accessories are used including papillotomes, cannulas, needle knifes, guide wires, biopsy forceps, biliary dilators, dilatation balloons, extraction balloons, Dormia basket, lithotripsors, laser lights and more recently an endoscope e.g. spyglass can be passed through the main ERCP scope to access within the biliary ductal system for direct visualization and performing a variety of interventions as well [4].

\section{Cirrhosis: Surgery versus endoscopy}

Liver cirrhosis is a prevalent disease and is caused by different etiologies. In our community we have a relatively high prevalence rates of HCV. Consequently, most of our patients are post-hepatitic cirrhosis. Child score was developed to assess the functional capacity of the diseased liver and is used to predict the morbidity and mortality among cirrhotic patients and is widely used due to the ease of its calculation and its reproducibility but unfortunately have many limitations [5]. In this score patients are given scores for five clinical measures of liver disease. Each measure is scored 1-3, with 3 indicating most severe derangement (Table 1). Child class A score is 56 , while $\mathrm{B}$ is $7-9$ and class $\mathrm{C}$ score range from 10-15.

Cirrhotic patients tolerate surgery badly and it has been proposed that the morbidity and mortality parallels the progression of liver disease. This means that patients with Child C cirrhosis are a very high risk of morbidity and mortality when compared with patients of Child A cirrhosis [6,7] when exposed to the same surgical interventions for the operable situations. When, patients are inoperable and a palliative surgery is inevitable it is expected to have major morbidity and mortality [8].

\section{Biliary malignancy}

Unfortunately, most of the cirrhotic patients present late inoperable in their course, have either locally extensive or metastatic disease and have an extremely grim prognosis. At this time, palliative treatment is preferably carried out by ERCP aiming at both relieving jaundice and improving quality of life by endoscopic biliary stenting [9].

Surgery carries a high risk of morbidity and mortality among cirrhotic patients and consequently alternatives including ERCP may be advisable than surgery [8].

\section{Cholelithiasis}

Surgical CBD exploration (either by conventional or laparoscopic surgery) is compared to ERCP in several studies $[\mathbf{1 0 , 1 1 ]}$. In our institution CBD exploration no more recommended for lone CBD stones except after failure of ERCP to retrieve CBD stones. In these circumstances ERCP is the best choice especially when the CBD stones are small. In fact during the last decades different technologies and interventions have been developed for retrieval of large CBD stones including large papillary dilatation, different modalities of lithotripsy and more recently laser fragmentation with the use of spyglass with acceptable success rates $[\mathbf{1 2 , 1 3}$. ERCP in these situations had another advantages that is a second look. A second look ERCP seems successful in a great proportion of cases when edema from the earlier ERCP is relived particularly when other techniques e.g. large balloon dilatation are used [14].

\section{Benign biliary strictures}

The list of benign biliary strictures causes among cirrhotics, like non cirrhotics, is long. However, the most common causes include surgical intervention of the biliary system mainly following liver transplantation and cholecystectomy. It is largely accepted that benign biliary strictures are managed by endoscopic biliary dilatation and stenting over multiple sessions and surgery is reserved for failed cases [15].

\section{ERCP among cirrhotics: Indications}

In Egypt, our experience in managing cirrhotic and HCV infected patients have been improved over the last decades with the introduction of interferon based and direct antiviral therapies and this yield an improved longevity among those patients [16-19]. Consequently, it is a daily medical practice to see cirrhotic patients in the ERCP theaters [17] face to face and as an endoscopist you have to tailor the treatment 
decision case by case according to the indications and health status of the patient among others.

Our research group have a great interest not only in the endoscopic management of hepatobiliary disorders among cirrhotics but also in studying this group of patients. In earlier studies $[12,18,20]$ we proved safety and efficacy of some invasive and advanced ERCP interventions in cirrhotics with acceptable adverse events rates (Table 2).

Cirrhotic patients like others have a wide list of indications for ERCP. The indications of ERCP among cirrhotics are not markedly different from non cirrhotics. However, the biliary stones (cholelithiasis) are three times more frequently encountered among cirrhotic patients in comparison to the others $[\mathbf{1 7 , 2 1 ]}$. This may be the main indication for ERCP among cirrhotics [22]. But, they are still prone to biliary malignancies, strictures and even infections. Diagnosis and treatment of portal biliopathy that includes abnormalities in the intrahepatic and extrahepatic biliary tract, gallbladder and cystic duct secondary to portal hypertension mostly caused by distended venous collateral is another unique indication for ERCP among hepatic patients [17,21]. The indications of ERCP among cirrhotics according to the most relevant studies are listed in Table 3 [23].

In our practice of ERCP in the subgroup of hepatic patients we were able to perform different interventions needed in the regular ERCP cases. We performed incomplete and complete sphincterotomy, needle knife papillotomy and fistulotomy, biliary balloon dilatation, extraction balloon application, Dormia Basket use, stent insertion and different types of biopsy similar to the regular cases $[12,18,20]$.

\section{ERCP among cirrhotics: Adverse events}

The complications of ERCP are commonly referred as to adverse events and its frequency varies across the literature which ranges from $3 \%$ to $9.8 \%$. With mortality reported up to $1 \%$. The most commonly encountered is post ERCP pancreatitis (PEP) with variable frequency rates [24]. However, most of the cases are mild to moderate and severe post ERCP pancreatitis is encountered only in minority of cases [25]. Other adverse events include ascending cholangitis, bleeding, perforations and complications of sedations and anesthesia and sometimes complications related to the contrast used [26]. The frequency of adverse events is expected to be higher among cirrhotic patients (Table 4), but why? Simply because cirrhosis is associated with impaired hepatic detoxification function exposing patients to complications of sedatives and anesthetic drugs, also cirrhotic patients tolerate stress badly, as well as impaired immunity predispose them to higher infectious complications particularly with increasing Child class $[\mathbf{1 2}, \mathbf{1 8 , 2 4 - 2 8}]$. On the other hand, bleeding is the expected adverse event to be high among cirrhotics due to both coagulopathy and low platelet count [18]. A recent meta-analysis showed that patients with cirrhosis had higher overall rates of complications compared to noncirrhosis [23].

The most commonly encountered adverse event after ERCP is PEP with the incidence of clinically significant PEP ranges from 1-15.7\% $[\mathbf{2 3}, 29,30]$. The situation in cirrhotics is quite different with PEP comes second after bleeding with rates that ranges between $3.06 \%$ and $5.7 \%$ and most of the cases were not severe and managed conservatively [12,18,23, 27].

We face cirrhotic patients with different classes of Child classification and we believe that our optimization of the preoperative condition of these patients stands behind the acceptable outcomes we reported particularly bleeding diathesis. In our daily practice we use fresh frozen plasma and Vit $\mathrm{K}$ injections when prothrombin time is prolonged $[\mathbf{1 2}, \mathbf{1 8}]$. Patients with child class $\mathrm{C}$ cirrhosis are critically ill and any intervention among them is associated with high morbidity and mortality $[\mathbf{2 9 , 3 0 ]}$. In our studies we excluded these patients from interventions and in our daily practice we direct them to other less invasive interventions when needed.

Due to the impaired hemostasis in the course of liver cirrhosis bleeding is expected to be high. This is reflected to the complications reported among cirrhotics during ERCP. Bleeding is the most frequently reported adverse event among cirrhotics with rates of $1.1 \%$ to $15.7 \%$ $[12,18,23,31]$.

Among patients with liver cirrhosis we proved that invasive techniques $[\mathbf{1 2 , 1 8}]$ including needle knife fistulotomy and large balloon dilatation can be performed at no extra cost of adverse events when carefully pre-operatively prepared and selected. We give our patients parenteral vit $\mathrm{K}$ 
and IV fresh frozen plasma before ERCP if the PT exceeds 16. In one study during the procedure the bleeding (6/11 patients) was mild and stopped either by cautery or after diluted adrenaline flushing, while delayed bleeding (5/11patients, all presented with melena) was treated conservatively and with blood transfusion and plasma, neither surgery nor therapeutic angiography were needed in all cases [18].

Cirrhotic patients are highly susceptible to infections [32] and it accounts for major morbidity and mortality among them and occurrence of cholangitis (one of the major adverse events of ERCP) is expected to add a burden to the ill situation of those patients.

Although the frequency of infections after ERCP is not high like pancreatitis with average rate of $1.4 \%$ yet the mortality from infectious complications are high as $7.85 \%[\mathbf{3 2 , 3 3 ]}$. Risk factors for post-ERCP infections including cholangitis are numerous and include the use of combined percutaneous and endoscopic procedures, stent placement in malignant strictures, the presence of jaundice, low case volume, and incomplete or failed biliary drainage [29]. In one study of our team we reported high frequency of cholangitis (25\%) at 6 months in a cohort of cirrhotic patients after double plastic stent insertion for inoperable malignant biliary strictures without any mortality. All patients in this study performed sphincterotomy and balloon dilatation before stents insertion [20].

Alder et al., [27], studied 328 patients with liver cirrhosis and they included patients with Child $\mathrm{A}, \mathrm{B}$ and $\mathrm{C}$ cirrhosis and they concluded that: There was a higher incidence of adverse events in patients with Child class B and C disease when compared with those with class A disease
$(11.4 \%, 11.3 \%$, and $6.1 \%$, respectively; $\mathrm{P}=0.048)$. They reported pancreatitis as the most common adverse event in contrary to our conclusions about bleeding this may be due to larger number of patients in their study and that all our patients were post viral cirrhosis. Furthermore, they concluded that the adverse events seen in patients with cirrhosis are similar to those seen in the general population of patients undergoing ERCP.

Navaneetan et al., [29] carried out one of the largest studies among cirrhotic patients. They compared between patients with liver cirrhosis $(\mathrm{n}=3228)$ and without liver cirrhosis (controls, $n=12$ 912). Adverse events and safety of inpatient ERCP were the outcomes of this study. Of the 3228 cirrhotic patients, $2603(80.6 \%)$ had decompensated and $625 \quad(19.4 \%)$ had compensated disease. Post-procedure bleeding $(2.1 \%$ vs. $1.2 \%, \mathrm{P}<0.01)$ was higher in patients compared to controls. On multivariable analysis, decompensated cirrhosis, compensated cirrhosis, therapeutic ERCPs, and biliary sphincterotomy were independently associated with increased risk of post-procedure bleeding. Performing ERCPs in large and medium sized hospitals was associated with a decreased risk of postprocedure bleeding. Biliary sphincterotomy and therapeutic ERCPs increased the risk of postERCP pancreatitis, and pancreatic stent placement was associated with a decreased risk of post-ERCP pancreatitis. They concluded that cirrhosis whatever (compensated or decompensated), performing therapeutic ERCPs and biliary sphincterotomy increase the risk of post-procedure bleeding. Performing ERCPs in large and medium sized hospitals may improve outcomes.

Table (1): Child-Turcotte-Pugh functional classification of chronic liver disease.

\begin{tabular}{|l|c|c|c|}
\hline \multicolumn{1}{|c|}{ Measure } & 1 point & 2 point & 3 point \\
\hline Total bilirubin, $\mu \mathrm{mol} / \mathrm{L}(\mathrm{mg} / \mathrm{dL})$ & $<34(<2)$ & $34-50(2-3)$ & $>50(>3)$ \\
\hline Serum albumin, $\mathrm{g} / \mathrm{dL}$ & $>3.5$ & $2.8-3.5$ & $<2.8$ \\
\hline Prothrombin time, prolongation (s) OR & $<4.0$ & $4.0-6.0$ & $>6.0$ \\
INR & $<1.7$ & $1.7-2.3$ & 2.3 \\
\hline Ascites & None & Mild (or suppressed with & Moderate to severe (or \\
\hline Hepatic encephalopathy & None & Gradication) & refractory) \\
\hline
\end{tabular}


Table (2): Our studies focusing cirrhotic patients.

\begin{tabular}{|c|c|c|c|c|}
\hline Study & Patients & End points & Results & Comments \\
\hline $\begin{array}{l}\text { El-Naggar et } \\
\text { al., 2013[18] }\end{array}$ & $\begin{array}{l}70 \text { cirrhotic patients } \\
\text { class A and B with } \\
\text { failed papillary } \\
\text { cannulation by the } \\
\text { standard techniques }\end{array}$ & \begin{tabular}{|cc|} 
& \multicolumn{2}{c}{ successful } \\
cannulation of the \\
CBD comparing \\
needle r & knife \\
fistulotomy & with \\
other techniques \\
- Post- ERCP adverse \\
events
\end{tabular} & 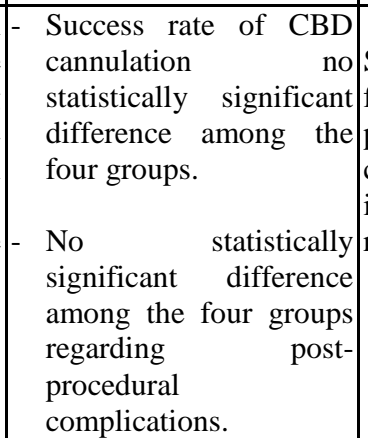 & $\begin{array}{l}\text { Suprapapillary needle }- \text { knife } \\
\text { fistulotomy can be used in cirrhotic } \\
\text { patients when standard biliary } \\
\text { cannulation proves to be difficult, } \\
\text { it is associated with a high success } \\
\text { rate and a low complication risk. }\end{array}$ \\
\hline $\begin{array}{l}\text { Radwan et al., } \\
\text { 2018[12] }\end{array}$ & $\begin{array}{l}\text { Ninety-eight } \\
\text { cirrhotic patients } \\
\text { with calcular } \\
\text { obstructive jaundice. } \\
\text { Group A comprised } \\
49 \text { patients treated by } \\
\text { LBD and group B } \\
\text { comprised } \\
49 \text { patients treated by } \\
\text { ML. All patients } \\
\text { underwent } \\
\text { sphincterotomy } \\
\text { initially. }\end{array}$ & 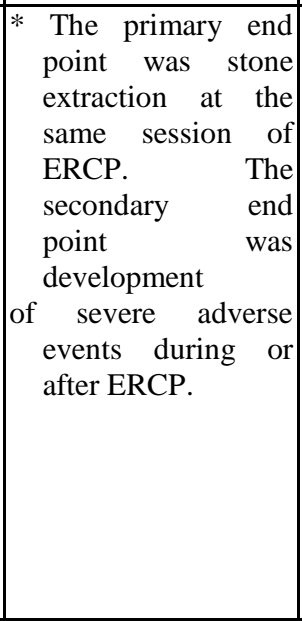 & $\begin{array}{l}\text { * The success rate for } \\
\text { CBD clearance was } \\
98 \% \text { and } 93.8 \% \text { for } \\
\text { LBD and ML, } \\
\text { respectively. The rate of } \\
\text { adverse events in this } \\
\text { study was } 10.2 \% \\
(10 / 98) \text {, and bleeding } \\
\text { was the commonest } \\
\text { reported complication } \\
\text { (5/10). Group B } \\
\text { developed r more } \\
\text { (16.3\%) adverse events } \\
\text { than group A (4.1\%), } \\
\text { and the difference was } \\
\text { statistically significant } \\
\text { (P=0.04). }\end{array}$ & $\begin{array}{l}\text { Endoscopic sphincterotomy } \\
\text { followed by LBD is a safe and } \\
\text { effective treatment for large CBD } \\
\text { stones in cirrhotic patients in } \\
\text { comparison with sphincterotomy } \\
\text { followed by ML. }\end{array}$ \\
\hline \begin{tabular}{|l|} 
Radwan et al., \\
2019 [20]
\end{tabular} & $\mid \begin{array}{lr}72 \text { Child } & \text { A } \\
\text { cirrhotic } & \text { patients } \\
\text { with } & \text { inoperable } \\
\text { malignant } & \text { biliary } \\
\text { obstruction } & \end{array}$ & \begin{tabular}{|l} 
- \\
Double plastic tent \\
patency at \\
months \\
- Cost effectiveness of \\
double plastic \\
stenting \\
- Quality of life \\
- Averse events
\end{tabular} & $\begin{array}{l}\text {-92\% of patients had their } \\
\text { stents patent at } 6 \\
\text { months } \\
\text { - Very low cots } \\
\text { - Significant improvements } \\
\text { in the symptomatology } \\
\text { and quality of life } \\
\text { - 25\% and 8\% of patients } \\
\text { developed cholangitis } \\
\text { and pancreatitis } \\
\text { respectively }\end{array}$ & $\begin{array}{l}\text { When the resources are low and } \\
\text { patients are not covered by health } \\
\text { insurance, double plastic stenting is } \\
\text { an acceptable cost effective } \\
\text { palliation for inoperable malignant } \\
\text { biliary stricture among cirrhotics. }\end{array}$ \\
\hline
\end{tabular}

Table (3): Indications of ERCP in cirrhotics.

\begin{tabular}{|l|c|c|}
\hline \multicolumn{1}{|c|}{ Indication } & Frequency & Number of studies analyzed \\
\hline Choledocholithiasis & $60.9 \%$ & 13 \\
\hline Cholangitis & $15.5 \%$ & 13 \\
\hline Biliary strictures & $26.2 \%$ & 14 \\
\hline Gallstone pancreatitis & $21.1 \%$ & 9 \\
\hline
\end{tabular}


Table (4): Post-ERCP complications among cirrhotics.

\begin{tabular}{|c|c|c|c|c|c|}
\hline \multirow{2}{*}{ Study } & \multicolumn{2}{|c|}{ Morbidity } & \multirow{2}{*}{ Mortality } & \multirow{2}{*}{ Preoperative preparation } & \multirow{2}{*}{ Comments } \\
\hline & $\mathrm{N}$ & $\%$ & & & \\
\hline \multicolumn{6}{|c|}{ El-Naggar et al., [18]: Single center prospective study } \\
\hline Pancreatitis & 4 & $5.7 \%$ & \multirow[t]{5}{*}{$1(1.4 \%)$} & \multirow{5}{*}{$\begin{array}{l}\text { vitamin K IV, } 10 \mathrm{mg} / \text { day }) \text { for } 3 \\
\text { days before ERCP. } \\
\text { Fresh frozen plasma }(10-15 \\
\text { ml/kg) was given immediately } \\
\text { before the endoscopy if the } \\
\text { prothrombin time was > } 16 \\
\text { seconds }\end{array}$} & \multirow{5}{*}{$\begin{array}{l}\text { Bleeding (immediate and } \\
\text { delayed) was the most } \\
\text { common complication in } \\
\text { this study. And all cases } \\
\text { managed conservatively } \\
\text { without need for surgery or } \\
\text { interventional radiology. } \\
\text { Prolonged }\end{array}$} \\
\hline Cholangitis & 1 & $1.4 \%$ & & & \\
\hline Bleeding & 11 & $15.7 \%$ & & & \\
\hline Perforations & 0 & 0 & & & \\
\hline Hepatic encephalopathy & 1 & $1.4 \%$ & & & \\
\hline \multicolumn{6}{|c|}{ Radwan et al., [12]: Single center prospective study } \\
\hline Pancreatitis & 3 & $3.06 \%$ & & \multirow{3}{*}{$\begin{array}{l}\text { vitamin } \mathrm{K} \mathrm{IV}, 10 \mathrm{mg} / \text { day }) \text { for } 3 \\
\text { days before ERCP. } \\
\text { Fresh frozen plasma }(10-15 \\
\mathrm{ml} / \mathrm{kg}) \text { was given immediately } \\
\text { before the endoscopy if the } \\
\text { prothrombin time was }>16 \\
\text { seconds }\end{array}$} & \multirow{3}{*}{$\begin{array}{l}\text { Patients treated with } \\
\text { mechanical lithotripsy } \\
\text { developed more }(16.3 \%) \\
\text { adverse } \\
\text { events than patients treated } \\
\text { with large balloon dilatation } \\
(4.1 \%) \text {, and the difference } \\
\text { was statistically } \\
\text { significant }(\mathrm{P}=0.04) \text {. }\end{array}$} \\
\hline Cholangitis & 2 & $2.04 \%$ & & & \\
\hline Bleeding & 5 & $5.1 \%$ & & & \\
\hline \multicolumn{6}{|c|}{ Adler et al., [27]: Multicenter retrospective study } \\
\hline Pancreatitis & 25 & $4.6 \%$ & \multirow[t]{7}{*}{$1(0.2 \%)$} & \multirow{7}{*}{$\begin{array}{l}\text { Thrombocytopenia } r \\
\text { coagulopathy were corrected } \\
\text { before ERCP. }\end{array}$} & \multirow{7}{*}{$\begin{array}{l}\text { cirrhotics without primary } \\
\text { sclerosing cholangitis had } \\
\text { significantly greater adverse } \\
\text { event rates when compared } \\
\text { with patients } r \text { having } \\
\text { primary } \\
\text { cholangitis. } \\
\text { There was a higher } \\
\text { incidence of adverse events } \\
\text { in patients with CP class B } \\
\text { and C disease when } \\
\text { compared with those with } \\
\text { CP class A disease }\end{array}$} \\
\hline Cholangitis & 15 & $2.8 \%$ & & & \\
\hline Bleeding & 6 & $1.1 \%$ & & & \\
\hline Perforations & 2 & $0.4 \%$ & & & \\
\hline aspiration pneumonia & 5 & $0.9 \%$ & & & \\
\hline Bile leakage & 1 & $0.2 \%$ & & & \\
\hline Cholecystitis & 1 & $0.2 \%$ & & & \\
\hline
\end{tabular}

\section{CONCLUSION}

The art of managing cirrhotic patients with ERCP is a team work and not a one man show. In fact the treatment begin from the most senior clinician who take the decision of ERCP based on a clear indication and pass through the most junior resident who carry out the task of performing the wise preoperative recommendations in order to optimally prepare the cirrhotic patient to ERCP. The endoscopist performs a great job when he carefully chooses the ideal decision regarding manipulations, interventions and accessories used in the least needed time. Stands behind the vision are the anesthesiologists who play a major role in choosing the ideal drugs with least impact on the diseased liver. The entire team members share in the favorable outcomes including the acceptable adverse events rates reported throughout the literature focusing cirrhotic patients.
Acknowledgment: We would thank all colleagues who helped us in conducting this work. No funds have been received for this work.

Funding: None

\section{Conflict of interest: None}

Author contribution: All authors shared in conception of the idea, searching the literature, drafting the manuscript and all approved the final manuscript

\section{REFERENCES}

1. Kozarek RA. The Past, Present, and Future of Endoscopic Retrograde Cholangiopancreatography. Gastroenterol Hepatol 2017; 13(10):620-622.

2. Wani S, Keswani RN, Petersen B, Edmundowicz SA, Walsh CM, Huang $C$ et al. Training in EUS and ERCP: standardizing methods to assess competence. Gastrointest Endosc 2018; 87 (6): 1371-1382. 
3. Domagk D, Oppong KW, Aabakken L, Czakó L, Gyökeres T, Manes $\mathrm{G}$ et al. Performance measures for endoscopic retrograde cholangiopancreatography and endoscopic ultrasound: A European Society of Gastrointestinal Endoscopy (ESGE) Quality Improvement Initiative. United European Gastroenterol J 2018 Dec; 6(10): 1448-1460.

4. Schutz SM. Grading the degree of difficulty of ERCP procedures. Gastroenterol Hepatol 2011; 7(10):674-6.

5. Peng Y, Qi X, Guo X. Child-Pugh Versus MELD Score for the Assessment of Prognosis in Liver Cirrhosis: A Systematic Review and MetaAnalysis of Observational Studies. Medicine (Baltimore). 2016; 95(8):e2877.

6. Hemida K, Al Swaff RE, Shabana SS, Said H, Ali-Eldin F. Prediction of Post-operative Mortality in Patients with HCV-related Cirrhosis Undergoing Non-Hepatic Surgeries. J Clin Diagn Res. 2016; 10(10):18-21.

7. Friedman LS. Surgery in the patient with liver disease. Trans Am Clin Climatol Assoc. 2010; 121:192-205.

8. Avishai Z, David JP. Morbidity and mortality in cirrhotic patients undergoing anesthesia and surgery. Current Opinion in Anaesthesiology 2001; 14(6):707-711

9. Baron TH. Palliation of malignant obstructive jaundice. Gastroenterol Clin North Am 2011; 35:101-12.

10. Gao YC, Chen J, Qin Q, Chen H, Wang W, Zhao J et al. Efficacy and safety of laparoscopic bile duct exploration versus endoscopic sphincterotomy for concomitant gallstones and common bile duct stones: A meta-analysis of randomized controlled trials. Medicine (Baltimore). 2017; 96(37): e7925.

11. Jinfeng Z, Yin Y, Chi Z, Junye G. Laparoscopic management after failed endoscopic stone removal in nondilated common bile duct. International Journal of Surgery 2016; 29: 49-52

12. Radwan MI, Emara MH, Ibrahim IM, Moursy ME. Large Balloon Dilatation Versus Mechanical Lithotripsy After Endoscopic Sphincterotomy in the Management of Large Common Bile Duct Stones in Cirrhotic Patients: A Randomized Study. J Clin Gastroenterol. 2019 Apr; 53(4):e150-e156.

13. Stefanidis G, Christodoulou C, Manolakopoulos S, Chuttani R. Endoscopic extraction of large common bile duct stones: A review article. World J Gastrointest Endosc. 2012; 4(5):167-79.

14. Berry R, Han JY, Tabibian JH. Difficult biliary cannulation: Historical perspective, practical updates, and guide for the endoscopist. World $J$ Gastrointest Endosc. 2019; 11(1):5-21.
15. AKP Shanbhogue, SH Tirumani, SR Prasad, N Fasih, M McInnes. Benign Biliary Strictures: A Current Comprehensive Clinical and Imaging Review. American Journal of Roentgenology 2011; 197(2):295-306.

16. Emam M, Radwan MI, Refaey MM, Shaheen NE, Abd-ElMoez S, Gerges MA. Prevalence of hepatitis $\mathrm{C}$ virus in an elderly population in rural areas of Sharkia governorate, Egypt. Egyptian Liver Journal 2015; 5(2):29-33.

17. Bassiony MA, Omran A. Endoscopic Retrograde Cholangiopancreatography (ERCP) in Cirrhotic Patients. Afro-Egypt J Infect Endem 2013; 3(3): 115-117.

18. El-Naggar YA, Radwan MI, Emara MH. NeedleKnife Fistulotomy as a Rescue Access of the Common Bile Duct in Cirrhotic Patients: Feasibility and Outcome. Afro-Egypt $J$ Infect Endem Dis 2013; 3(4): 135-145.

19. Gomaa A, Allam N, Elsharkawy A, El Kassas M, Waked I. Hepatitis C infection in Egypt: prevalence, impact and management strategies. Hepat Med. 2017; 9:17-25.

20. Radwan MI, Emara MH, Zaghloul MS, Zaghloul AMS. Double plastic stenting for inoperable malignant biliary stricture among cirrhotic patients as a possible cost-effective treatment: a pilot study. Eur J Gastroenterol Hepatol. 2019 Aug; 31(8):1057-1063

21. Zhou Y-F, Zhang X, Zhang X-f, Guo Y LV. Wen, Lin $X$ et al. ERCP in patients with Iiver cirrhosis : analysis of 156 cases. Chin $J$ Hepatobiliary Surgery 2009; 15 (9):647-650

22. Macías-Rodríguez RU, Ruiz-Margáin A, Rodriguez-Garcia JL, Zepeda-Gómez S, Torre A. Risk factors associated with complications in cirrhotic patients undergoing endoscopic retrograde cholangio-pancreatography. Eur $J$ Gastroenterol Hepatol. 2017; 29(2):238-243.

23. Mashiana HS, Dhaliwal AS, Sayles H, Dhindsa B, Yoo JW, Wu Q et al. Endoscopic retrograde cholangiopancreatography in cirrhosis - a systematic review and meta-analysis focused on adverse events. World J Gastrointest Endosc 2018; 10(11): 354-366.

24. Freeman ML, Nelson DB, Sherman S, Haber GB, Herman ME, Dorsher PJ et al. Complications of endoscopic biliary sphincterotomy. $N$ Engl J Med. 1996 Sep 26; 335(13):909-18.

25. Cotton PB, Lehman G, Vennes J, Geenen JE, Russell RC, Meyers WC et al. Endoscopic sphincterotomy complications and their management: an attempt at consensus. Gastrointest Endosc 1991; 37:383-93. 
26. ASGE Standards of Practice Committee, Chandrasekhara V, Khashab MA, et al. Adverse events associated with ERCP. Gastrointest Endosc. 2017; 85(1):32-47.

27. Adler DG, Haseeb A, Francis G, Kistler CA, Kaplan J, Ghumman SS et al. Efficacy and safety of therapeutic ERCP in patients with cirrhosis: a large multicenter study. Gastrointest Endosc. 2016 Feb; 83(2):353-9.

28. Inamdar S, Berzin TM, Berkowitz J, Sejpal DV, Sawhney MS, Chutanni R et al. Decompensated cirrhosis may be a risk factor for adverse events in endoscopic retrograde cholangiopancreatography. Liver Int. 2016; 36(10): 1457-63.

29. Navaneethan U, Njei B, Zhu X, Kommaraju K, Parsi MA, Varadarajulu S. Safety of ERCP in patients with liver cirrhosis: a national database study. Endosc Int Open. 2017;5(4):E303-E314.
30. Loperfido S, Angelini G, Benedetti G, Chilovi F, Costan F, De Berardinis F et al. Major early complications from diagnostic and therapeutic ERCP: a prospective multicenter study. Gastrointest Endosc. 1998; 48(1):1-10.

31. Barthet M, Lesavre N, Desjeux A, Gasmi M, Berthezene P, Berdah $\mathrm{S}$ et al. Complications of endoscopic sphincterotomy: results from a single tertiary referral center. Endoscopy. 2002; 34(12):991-7.

32. Bunchorntavakul C, Chamroonkul N, Chavalitdhamrong D. Bacterial infections in cirrhosis: A critical review and practical guidance. World J Hepatol. 2016;8(6):307-21.

33. Andriulli A, Loperfido S, Napolitano G, Niro G, Valvano MR, Spirito $\mathrm{F}$ et al. Incidence rates of post-ERCP complications: a systematic survey of prospective studies. Am J Gastroenterol. 2007; 102(8):1781-8. 